\title{
UDP-Glucose:Glycoprotein Glucosyltransferase 2
}

National Cancer Institute

\section{Source}

National Cancer Institute. UDP-Glucose:Glycoprotein Glucosyltransferase 2. NCI

Thesaurus. Code C150053.

UDP-glucose:glycoprotein glucosyltransferase $2(1516 \mathrm{aa}, \sim 175 \mathrm{kDa})$ is encoded by the human UGGT 2 gene. This protein plays a role in the glucosylation of proteins with folding defects. 